\title{
Comparison in Terms of Safety and Efficacy between Fondaparinux and Enoxaparin in Acute Coronary Syndrome
}

\author{
Vinod Kumar ${ }^{1}$, Kavita Sharma², Ritu Bhagat ${ }^{3}$ \\ ${ }^{1}$ Assistant Professor, Department of Medicine, GMC, Doda, Jammu and Kashmir, India. \\ ${ }^{2}$ Senior Resident, Department of Medicine, GMC, Jammu, Jammu and Kashmir, India. \\ ${ }^{3}$ Senior Resident, Department of Pathology, GMC, Jammu, Jammu and Kashmir, India.
}

\section{ABSTRACT}

\section{BACKGROUND}

Cardiovascular disease (CVD) has become the most common cause of death worldwide. Today, it accounts for approximately $30 \%$ of deaths worldwide including $40 \%$ in high income countries and about $28 \%$ in low- and middle-income countries. Coronary artery disease (CAD) is typically defined as more than $50 \%$ stenosis of any epicardial coronary artery. Acute coronary syndrome (ACS) refers to a constellation of clinical signs and symptoms produced by acute myocardial ischemia. It includes unstable angina (UA), ST- segment elevation myocardial infarction (STEMI), and nonST-segment elevation myocardial infarction (NSTEMI). The initial diagnosis of ACS is based on history, risk factors, and to the associated electrocardiogram (ECG) findings. We wanted to compare the efficacy and safety of fondaparinux with that of enoxaparin in patients of acute coronary syndrome.

\section{METHODS}

This is a prospective interventional study of one year from Nov. 2014 to Dec. 2015 conducted in GMC Jammu. A total of 180 patients were included in the study. Of these, 90 patients were given fondaparinux and remaining 90 patients were given enoxaparin randomly.

\section{RESULTS}

In the present study, there was no episode of major bleeding in both the study groups. The difference between the two groups was $1.11 \%$, in terms of minor bleeding, which was not statistically significant.

\section{CONCLUSIONS}

We conclude that fondaparinux is as effective as enoxaparin in the early prevention of major outcomes in acute coronary syndrome. In addition, fondaparinux appears to be safe in terms of bleeding risk than enoxaparin, a benefit which may lead to longterm reduction in ischemic complications and death.

\section{KEY WORDS}

Acute Coronary Syndrome, Coronary Artery Disease, Myocardial Infarction

\author{
Corresponding Author: \\ Dr. Kavita Sharma, \\ RTO, Udhampur, \\ Jammu and Kashmir, \\ India. \\ E-mail: drrkatil76@gmail.com \\ DOI: $10.14260 / \mathrm{jemds} / 2019 / 548$ \\ Financial or Other Competing Interests: \\ None. \\ How to Cite This Article: \\ Kumar V, Sharma K, Bhagat R. Comparison \\ in terms of safety and efficacy between \\ fondaparinux and enoxaparin in acute \\ coronary syndrome. J. Evolution Med. Dent. \\ Sci. 2019;8(31):2519-2522, DOI: \\ $10.14260 /$ jemds/2019/548
}

Submission 12-06-2019,

Peer Review 13-07-2019,

Acceptance 22-07-2019,

Published 05-08-2019. 


\section{BACKGROUND}

Cardiovascular disease (CVD) became the most common cause of death worldwide. Today, it accounts for approximately $30 \%$ of deaths worldwide including $40 \%$ in high income countries and about $28 \%$ in low- and middle-income countries. Coronary artery disease (CAD) is typically defined as a more than $50 \%$ stenosis of any epicardial coronary artery. Acute coronary syndrome (ACS) refers to a constellation of clinical signs and symptoms produced by acute myocardial ischemia. It comprises unstable angina (UA), ST- segment elevation myocardial infarction (STEMI), and non-ST-segment elevation myocardial infarction (NSTEMI). The initial diagnosis of ACS is based on history, risk factors and to the associated electrocardiogram (ECG) findings. It was hypothesized that selective Xa inhibitors of coagulation factors located further upstream in the coagulation pathway might be safer with respect to bleeding by not inhibiting thrombin activity directly. Factor Xa has been identified as a potential target for the design of new anticoagulants as selective inhibitors. Xa would effectively block coagulation. ${ }^{1}$ Fondaparinux sodium is the first in a new class of antithrombotic agents that selectively inhibit factor Xa. It is a small, totally synthetic molecule, developed based on the native penta saccharide sequence (In heparin) that binds to antithrombin III and potentiates its antifactor Xa activity.,2,3 Fondaparinux binds specifically to antithrombin III and not to irrelevant plasma proteins, ${ }^{5}$ exhibits no inhibitory effect on platelet aggregation, ${ }^{6}$ and is unlikely to be associated with clinical heparin-induced thrombocytopenia, according to the results of studies conducted to date. $6,7,8,9$

\section{Aim of the Study}

Comparison of efficacy and safety of fondaparinux with that of enoxaparin in patients of acute coronary syndrome.

\section{METHODS}

This is a prospective interventional study undertaken in Postgraduate Department of Medicine and Cardiac Care Unit of Government Medical College Hospital, Division of Cardiology, Jammu, during a period of 1-year w.e.f. November 2014 to December 2015. A total of 180 patients were included in the study. Sample size was taken based on the convenience of the study. Of these, 90 patients were given fondaparinux and remaining 90 patients were given enoxaparin randomly. Randomization and was done by using computer generated random number table. All patients of acute coronary syndrome, who fulfilled the eligibility criteria, admitted in Cardiac Care Unit during the period of study were the subjects. After fully explaining the purpose of study and seeking written consent, the subjects were requested to participate in the study. Got approval from IEC and consent was taken from all patients.

\section{Inclusion Criteria}

1. All patients aged above 18 years and below 75 years, irrespective of convenient risk factors like hypertension, diabetes mellitus, etc.
2. Both sexes are included

3. Patients diagnosed with unstable angina pectoris, STelevation MI, NSTEMI on the basis of history, physical examination, ECG changes and serum cardiac biomarkers.

\section{Exclusion Criteria}

1. Patients undergoing percutaneous coronary intervention (PCI).

2. Patients with active clinically significant bleeding, severe renal impairment (GFR $<30 \mathrm{ml} / \mathrm{hr}$ ), presence of heparininduced thrombocytopenia (HIIT)-type II, acute bacterial endocarditis, known hypersensitivity to fondaparinux or its excipients.

3. Patients weighing under $50 \mathrm{~kg}$; patients with severe hepatic impairment.

\section{Statistical Analysis}

At the end of the study, all the data was entered in Microsoft excel and analysis was done using SPSS version 22. Baseline characteristics in the two study groups were evaluated using chi-square test. A p-value of $<0.05$ was considered statistically significant.

\section{RESULTS}

In fondaparinux group, $48(76.20 \%)$ males were smokers and $15(23.80 \%)$ were non-smokers, while 4 (14.81\%) females were smokers and 23 (85.19\%) were non-smokers. In enoxaparin group, 44 (70.97 \%) males were smokers and 18 $(29.03 \%)$ were non-smokers, while 6 (21.42 \%) females were smokers and $22(78.57 \%)$ were non-smokers. In fondaparinux group, $30(47.61 \%)$ males were diabetics and 33 (59.39\%) were non-diabetics, while 9 (33.33\%) females were diabetics and 18 (66.67\%) were non-diabetics. In enoxaparin group, 26 (41.93\%) males were diabetics and 36 (58.07\%) were non- diabetics, while 11 (39.18\%) females were diabetics and 17 (60.72\%) were non-diabetics. In fondaparinux group, $40(63.50 \%)$ males were hypertensive and $23(36.50 \%)$ were normotensive, while 10 (37.03\%) females were diabetics and $18(66.67 \%)$ were non-diabetics. In enoxaparin group, 26 (41.93\%) males were diabetics and $36(58.07 \%)$ were non-diabetics, while 11 (39.18\%) females were diabetics and $17(60.72 \%)$ were non-diabetics. In fondaparinux group, 3 (4.76\%) males had family history of IHD and 60 (95.24\%) did not had family history of IHD, while $2(7.40 \%)$ females had family history of IHD and 25 (92.60\%) did not had family history of IHD. In enoxaparin group, 26 (41.93\%) males were diabetics and 36 (58.07\%) were nondiabetics, while 11 (39.18\%) females were diabetics and 17 $(60.72 \%)$ were non-diabetics.

\begin{tabular}{|c|c|c|c|}
\hline Sex & $\begin{array}{c}\begin{array}{c}\text { Fondaparinux Group } \\
(\mathrm{n}=90) \text { No. }(\%)\end{array} \\
\end{array}$ & $\begin{array}{l}\text { moxaparin Group (n = } \\
\text { 90) No. }(\%)\end{array}$ & $\begin{array}{c}\text { Total }(n=180) \\
\text { No. }(\%)\end{array}$ \\
\hline Male & $63(70.00)$ & $62(68.89)$ & $125(69.44)$ \\
\hline Female & $27(30.00)$ & $28(31.11)$ & $55 \quad(30.56)$ \\
\hline \multicolumn{4}{|c|}{$\begin{array}{c}\text { Table 1. Sex Distribution of Patients Included in Fondaparinux Group } \\
\text { and Enoxaparin Group }\end{array}$} \\
\hline
\end{tabular}




\begin{tabular}{|c|c|c|c|c|}
\hline H/oSmoking & \multicolumn{2}{|c|}{ FondaparinuxGroup } & \multicolumn{2}{|c|}{ EnoxaparinGroup } \\
\hline & $\begin{array}{c}\text { Male }(n=63) \\
\text { No.(\%) }\end{array}$ & $\begin{array}{c}\text { Female }(\mathrm{n}=27) \\
\text { No. }(\%)\end{array}$ & $\begin{array}{c}\text { Male }(n=62) \\
\text { No. (\%) }\end{array}$ & $\begin{array}{c}\text { Female }(\mathbf{n}=28) \\
\text { No. }(\%)\end{array}$ \\
\hline Present & $48(76.20)$ & \begin{tabular}{|l|}
$4(14.81)$ \\
\end{tabular} & $44(70.97)$ & $6(21.42)$ \\
\hline Absent & $15(23.80)$ & $23(85.19)$ & $18(29.03)$ & $22(78.58)$ \\
\hline Total & 63 & 27 & 62 & 28 \\
\hline \multicolumn{5}{|c|}{$\begin{array}{l}\text { Table 2. Distribution of Patients Included in Fondaparinux Group and } \\
\text { Enoxaparin Group according to History of Smoking }\end{array}$} \\
\hline $\mathrm{X}^{2}=0.31 . \mathrm{p}=0.36$ (non & mificant) & & & \\
\hline
\end{tabular}

\begin{tabular}{|c|c|c|c|c|}
\hline & \multicolumn{2}{|c|}{ Fondaparinux Group } & \multicolumn{2}{c|}{ Enoxaparin Group } \\
\hline $\begin{array}{c}\text { H/o } \\
\text { Diabetes } \\
\text { Mellitus }\end{array}$ & $\begin{array}{c}\text { Male (n= 63) } \\
\text { No. (\%) }\end{array}$ & $\begin{array}{c}\text { Female }(\mathbf{n}=\mathbf{2 7}) \\
\text { No. (\%) }\end{array}$ & $\begin{array}{c}\text { Male (n= 62) } \\
\text { No. (\%) }\end{array}$ & $\begin{array}{c}\text { Female }(\mathbf{n}=\mathbf{2 8}) \\
\text { No. (\%) }\end{array}$ \\
\hline Present & $30(47.61)$ & $9(33.33)$ & $26(41.93)$ & $11(39.18)$ \\
\hline Absent & $33(52.39)$ & $18(66.67)$ & $36(58.07)$ & $17(60.72)$ \\
\hline Total & $\mathbf{6 3}$ & $\mathbf{2 7}$ & $\mathbf{6 2}$ & $\mathbf{2 8}$ \\
\hline $\begin{array}{r}\text { Table 3. Distribution of Patients Included in Fondaparinux Group and } \\
\text { Enoxaparin Group According to History of Diabetes Mellitus }\end{array}$ \\
\hline
\end{tabular}

\begin{tabular}{|c|c|c|c|c|}
\hline $\begin{array}{c}\text { H/o } \\
\text { Hypertension }\end{array}$ & \multicolumn{2}{|c|}{ Fondaparinux Group } & \multicolumn{2}{c|}{ Enoxaparin Group } \\
\cline { 2 - 5 } & $\begin{array}{c}\text { Male (n= } \\
\text { 63) No. (\%) }\end{array}$ & $\begin{array}{c}\text { Female (n= } \\
\text { 27) No. (\%) }\end{array}$ & $\begin{array}{c}\text { Male (n= } \\
\text { 62) No. (\%) }\end{array}$ & $\begin{array}{c}\text { Female (n = } \\
\text { 28) No. (\%) }\end{array}$ \\
\hline Present & $40(63.50)$ & $10(37.03)$ & $38(61.30)$ & $13(46.42)$ \\
\hline Absent & $23(36.50)$ & $17(62.97)$ & $24(38.70)$ & $15(53.58)$ \\
\hline Total & $\mathbf{6 3}$ & $\mathbf{2 7}$ & $\mathbf{6 2}$ & $\mathbf{2 8}$ \\
\hline $\begin{array}{r}\text { Table 4. Distribution of Patients Included in Fondaparinux Group and } \\
\text { Enoxaparin Group According to History of Hypertension }\end{array}$ \\
\hline \multicolumn{3}{|c|}{$\mathrm{x}^{2}=0.02 . \mathrm{p}=0.88$ (non-significant) } \\
\hline
\end{tabular}

\begin{tabular}{|c|c|c|c|c|}
\hline \multirow[b]{2}{*}{$\begin{array}{c}\text { Family H/o } \\
\text { IHD }\end{array}$} & \multicolumn{2}{|c|}{ Fondaparinux Group } & \multicolumn{2}{|c|}{ Enoxaparin Group } \\
\hline & $\begin{array}{c}\text { Male }(\mathrm{n}=63) \\
\text { No. }(\%)\end{array}$ & $\begin{array}{l}\text { Female }(n= \\
\text { 27) No. }(\%)\end{array}$ & $\begin{array}{c}\text { Male }(\mathrm{n}=62) \\
\text { No. }(\%)\end{array}$ & $\begin{array}{l}\text { Female }(\mathrm{n}= \\
\text { 28) No. (\%) }\end{array}$ \\
\hline Present & \begin{tabular}{|l|}
$3(4.76)$ \\
\end{tabular} & $2(7.40)$ & $2(3.20)$ & $1(3.57)$ \\
\hline Absent & $60(95.24)$ & $25(92.60)$ & $60(96.80)$ & 27 (96.43) \\
\hline Total & 63 & 27 & 62 & 28 \\
\hline
\end{tabular}

Table 5. Distribution of Patients Included in Fondaparinux Group and Enoxaparin Group According to Family History of Ischaemic Heart Disease $\mathrm{p}=0.72$ (non-significant)

\begin{tabular}{|c|c|c|c|c|}
\hline \multirow[b]{2}{*}{$\begin{array}{l}\text { Age Group } \\
\text { (in Years) }\end{array}$} & \multicolumn{2}{|c|}{ Fondaparinux Group ( $\mathrm{n}=90)$} & \multicolumn{2}{|c|}{ Enoxaparin Group $(\mathrm{n}=90)$} \\
\hline & $\begin{array}{l}\text { Fresh ST } \\
\text { Changes } \\
\end{array}$ & $\begin{array}{l}\text { No fresh ST } \\
\text { Changes }\end{array}$ & $\begin{array}{l}\text { Fresh ST } \\
\text { Changes } \\
\end{array}$ & $\begin{array}{c}\text { No Fresh ST } \\
\text { Changes }\end{array}$ \\
\hline $18-27$ & - & $1(100.00)$ & - & $1(100.00)$ \\
\hline $28-37$ & $\overline{-}$ & $8(100.00)$ & $\overline{-}$ & $8(100.00)$ \\
\hline $38-47$ & $2(14.28)$ & $12(85.72)$ & $1(8.33)$ & $11(91.67)$ \\
\hline $48-57$ & $1(3.33)$ & $29(96.67)$ & $1(3.03)$ & $32(96.67)$ \\
\hline $58-67$ & $1(3.57)$ & $27(96.43)$ & $3(13.04)$ & $20(86.96)$ \\
\hline $68-75$ & - & $9(100.00)$ & $1(7.69)$ & $12(97.31)$ \\
\hline Total & 4 & 86 & 6 & 84 \\
\hline
\end{tabular}

Table 6. ECG Findings in Fondaparinux Group and Enoxaparin In fondaparinux group, 4 (4.44\%) patients show recurrent ischemia/myocardial infarction (as evidenced by fresh ST changes).

\begin{tabular}{|r|c|c|c|c|}
\hline $\begin{array}{c}\text { Age Group } \\
\text { (In Years) }\end{array}$ & $\begin{array}{c}\text { Hemorrhage } \\
\text { No. (\%) }\end{array}$ & $\begin{array}{c}\text { Recurrent Ischemia } \\
\text { / MI No. \%) }\end{array}$ & $\begin{array}{c}\text { Sudden Death } \\
\text { No. (\%) }\end{array}$ & $\begin{array}{c}\text { Recovery No. } \\
\text { (\%) }\end{array}$ \\
\hline $18-27$ & - & - & - & $1(100.00)$ \\
\hline $28-37$ & - & - & - & $8(100.00)$ \\
\hline $38-47$ & - & $2(16.67)$ & - & $12(83.33)$ \\
\hline $48-57$ & - & $1(3.33)$ & - & $29(96.67)$ \\
\hline $58-67$ & $1(3.57)$ & $1(3.53)$ & - & $26(92.85)$ \\
\hline $68-75$ & - & - & - & $9(100.00)$ \\
\hline Total & $\mathbf{1}$ & $\mathbf{4}$ & - & $\mathbf{8 5}$ \\
\hline
\end{tabular}

Table 7. Primary End Points (at Day 9) in Fondaparinux Group

In the fondaparinux group, 4 (4.44 \%) patients had recurrent ischemia/Ml, 1 (1.11 $\%$ ) patient had hemorrhage (Major/Minor) and 85 patients showed recovery without any recurrent ischemia/MI/death/hemorrhage.

\begin{tabular}{|c|c|c|c|c|}
\hline $\begin{array}{c}\text { Age Group } \\
\text { (in Years) }\end{array}$ & $\begin{array}{c}\text { Hemorrhage } \\
\text { No. (\%) }\end{array}$ & $\begin{array}{c}\text { Recurrent Ischemia } \\
\text { /MI No. (\%) }\end{array}$ & $\begin{array}{c}\text { Sudden Death } \\
\text { No. (\%) }\end{array}$ & $\begin{array}{c}\text { Recovery } \\
\text { No. (\%) }\end{array}$ \\
\hline $18-27$ & - & - & & $1(100.00)$ \\
\hline $28-37$ & - & - & - & $8(100.00)$ \\
\hline $38-47$ & - & $1(8.33)$ & - & $11(96.67)$ \\
\hline $48-57$ & - & $1(3.03)$ & - & $32(96.67)$ \\
\hline $58-67$ & $1(4.35)$ & $3(13.04)$ & - & $19(82.60)$ \\
\hline $68-75$ & $1(7.69)$ & $1(7.69)$ & - & $11(84.61)$ \\
\hline Total & $\mathbf{2}$ & 6 & - & $\mathbf{8 2}$ \\
\hline
\end{tabular}

Table 8. Primary End Points (at Day 9) in Enoxaparin Group

In the fondaparinux group, 4 (4.44\%) patients had recurrent ischemia/Ml, 1 (1.11 $\%$ ) patient had hemorrhage (major/minor) and 85 patients showed recovery without any recurrent ischemia/MI/death/hemorrhage.

\begin{tabular}{|c|c|c|}
\hline Primary End Points & $\begin{array}{c}\text { Fondaparinux Group } \\
\text { (n= 90) No. (\%) }\end{array}$ & $\begin{array}{c}\text { Enoxaparin Group } \\
\text { (n = 90) No. (\%) }\end{array}$ \\
\hline Hemorrhage & $1(1.11)$ & $2(2.22)$ \\
\hline Recurrent ischemia/Ml & $4(4.44)$ & $6(6.66)$ \\
\hline Sudden death & & - \\
\hline Recovery & $85(94.44)$ & $82(91.11)$ \\
\hline Total & $\mathbf{9 0}$ & $\mathbf{9 0}$ \\
\hline
\end{tabular}

Table 9. Comparison Between Fondaparinux Group and Enoxaparin Group in Terms of Primary End Points

Fisher's Exact test $\mathrm{p}=1.00$ (non-significant) for hemorrhage. $\mathrm{X}^{2} \sim 0.42$. $\mathrm{p}=0.51$ (Nonsignificant) for recurrent ischemia/Ml.

\section{DISCUSSION}

This in-hospital study entitled "Comparison in terms of safety and efficacy between fondaparinux and enoxaparin in acute coronary syndrome" was undertaken in the Post Graduate Department of Medicine and Cardiac Care Unit of Government Medical College Hospital, Division of Cardiology, Jammu during a period of 1-year w.e.f. November 2014 to December 2015. A total of 180 patients were included in this study.

In the present study, out of 180 patients, 125 (69.44\%) were males and 55 (30.56\%) were females. In our study, 90 patients each were in the fondaparinux and enoxaparin group. In this study, there was 63 (70\%) males and 27 (30\%) females in the fondaparinux group, whereas there are $62(68.89 \%)$ males and $28(31.11 \%)$ females in the enoxaparin group. In the study by Budaj et al, 10 there was $62 \%$ males and $38 \%$ females which is almost similar to our study. In our study, the mean age was $53.9 \pm 11.35$ years in the fondaparinux group, and it was $53.65 \pm 12.76$ years in the enoxaparin group. In the study by Yusuf et al,11 mean age was $66.6 \pm 10.8$ years in fondaparinux group, and was $66.6 \pm 11.0$ years in the enoxaparin group. In our study, there were $63.5 \%$ hypertensive males in the fondaparinux group and $61.3 \%$ hypertensive males in enoxaparin group. In the study by Budaj et al,10 there were $66.9 \%$ hypertensive males, which is almost similar to that of our study. In our study, $43.33 \%$ patients were having diabetes in fondaparinux group and $41.11 \%$ were having diabetes in the enoxaparin group. In the study by Yusuf ef al,11 $25.3 \%$ patients were having diabetes in the fondaparinux group, and $25 \%$ were having diabetes in the enoxaparin group.

In our study, $55.55 \%$ patients were having hypertension in the fondaparinux group, whereas $56.67 \%$ patients were having hypertension in the enoxaparin group. In the study by Yusuf ef al,11 there were $67.4 \%$ and $67 \%$ patients in the fondaparinux and enoxaparin group, respectively. In our study, there were $57.78 \%$ and $55.56 \%$ smokers in the fondaparinux and enoxaparin group, respectively. In the study by Yusuf ef al, 11 there were $54.1 \%$ and $54.6 \%$ smokers in the fondaparinux and enoxaparin group, respectively. In the present study, ST depression >1 mm was present in $54.44 \%$ patients in both fondaparinux and enoxaparin group, respectively. In the study by Yusuf ef al, ${ }^{11}$ ST depression $>1$ mm was present in $51.7 \%$ patients and $50.3 \%$ patients in fondaparinux and enoxaparin group, respectively. In the present study, $4.44 \%$ patients $(n=4)$ in the fondaparinux group and $6.67 \%(\mathrm{n}=6)$ patients in the enoxaparin group showed the occurrence of recurrent ischemia/Ml as evidenced by ECG changes and troponin levels at day 9 .

In the study by Yusuf et al,11 the number of patients with primary outcome events (recurrent ischemia/Ml and death 
was similar in two groups (579 with fondaparinux (5.8\%) versus 573 with enoxaparin $5.7 \%$ ). In the present study, 1 patient $(1.11 \%)$ in the fondaparinux group and 2 patients $(2.22 \%)$ in the enoxaparin group developed haemorrhagic complications. In the study by Mehta et al,12 fondaparinux reduced major bleeding by $41 \%$ (3.4\% in control group versus $2.1 \%$ in the fondaparinux group). In the study by Yusuf et al, 11 the $2.2 \%$ patients $(n=217)$ in the fondaparinux group and $4.1 \%$ patients $(\mathrm{n}=412)$ in the enoxaparin group developed haemorrhagic complications showing a reduction of $48 \%$.

\section{CONCLUSIONS}

Fondaparinux is as effective as enoxaparin in the early prevention of major outcomes in acute coronary syndrome. In addition, fondaparinux appears to be safe in terms of bleeding risk than enoxaparin, a benefit which may lead to long-term reduction in ischemic complications and death.

\section{REFERENCES}

[1] Bauer KA. New anticoagulants. ASH Education Book 2006;1:450-6.

[2] Choay J, Petitou M, Lormeau JC, et al. Structure-activity relationship in heparin: a synthetic pentasaccharide with high affinity for antithrombin III and eliciting high antifactor Xa activity. Biochem Biophys Res Commun 1983;116(2):492-9.

[3] Van Boeckel CAA, Beetz T, Vos JN, et al. Synthesis of a pentasaccharide corresponding to the antithrombin III binding fragment of heparin. J Carbohydr Chem 1985;4(3):293-321.

[4] Petitou M, Duchaussoy P, Lederman l, et al. Synthesis of heparin fragments: a methyl a-pentaoside with high affinity for antithrombin III. Carbohydr Res 1987;167:6775 .
[5] Paolucci F, Clavies MC, Donat F, et al. Fondaparinux sodium mechanism of action: identification of specific binding to purified and human plasma-derived proteins. Clin Pharmacokinetic 2002;41 Suppl 2:11-18.

[6] Messmore HL Jr, Griffin B, Fareed J, et al. In vitro studies of the interaction of heparin, low molecular weight heparin and heparinoids with platelets. Ann N Y Acad Sci 1989;556:217-32.

[7] Elalamy I, LeCrubier C, Potevin F, et al. Absence of in vitro cross-reaction of pentasaccharide with the plasma heparin-dependent factors of twenty-five patients with heparin-associated thrombocytopenia [letter]. Thromb Haemost 1995;74(5):1384-5.

[8] Amiral J, Lormeau JC, Marfaing-Koka A, et al. Absence of cross-reactivity of SR90107A/ORG31540 pentasaccharide with antibodies to heparin-PF4 complexes developed in heparin-induced thrombocytopenia. Blood Coagul Fibrinolysis 1997;8(2):114-7.

[9] Ahmad S, Jeske WP, Walenga JM, et al. Synthetic pentasaccharides do not cause platelet activation by antiheparin-platelet factor 4 antibodies. Clin Appl Thromb Hemost 1999;5(4):259-66.

[10] Budaj A, Eikelboom JW, Wailentin L, et al. Bleeding complications predict major cardiovascular outcomes in non-ST-elevation acute coronary syndromes: results from the OASIS-5 trial. American College of Cardiology. http://www.acc.org/2006ann_meeting/home/home.ht m (Abstract 927-224).

[11] Yusuf S, Mehta SR, Chrolavicius S, et al. Comparison of fondaparinux and enoxaparin in acute coronary syndromes. N Engl J Med 2006;354(14):1464-76.

[12] Mehta SR, Boden WE, Eikelboom JW, et al. Antithrombotic therapy with fondaparinux in relation to interventional management strategy in patients with ST- and non-STsegment elevation acute coronary syndromes. Circulation 2008;118(20):2038-46. 